\title{
農産物流通多様化における「その他卸売市場」の生き残り戦略
}

\author{
武田 涁奈（岡山大学農学部） \\ 小松 泰信（岡山大学大学院環境学研究科） \\ 横溝功 (岡山大学大学院環境学研究科)
}

\section{Analyzing the Management Strategy for "Small-scale Wholesale Markets" by considering the Diversity in the Distribution of Agricultural Products}

\author{
Akina Taketa (Faculty of Agriculture, Okayama University) \\ Yasunobu Komatsu (Graduate School of Environmental Science, Okayama University) \\ Isao Yokomizo (Graduate School of Environmental Science, Okayama University)
}

The distribution rate in wholesale markets has decreased because of the diversity in the marketing of agricultural products.

Competition between wholesale markets has intensified because the unification and reorganization of wholesale markets by the government has led to the concentration of large-scale wholesale markets.

In this study, we focused on companies in small-

\section{1. 課題と方法}

近年, 情報・輸送の技術の発展により農産物の流 通形態が多様化している，消費者の多様なニーズが 反映された結果，インターネット販売，産地直売所 なぞ, 市場外流通が盛んに利用されるようになった。 小売店で大きな影響力を持つ大型スーパーチェーン は計画的販売のために契約栽培を利用するように なって扮り，今後も卸売市場経由率は減少する招そ れがある。ささらに，流通の効率化を目指した政策に より大規模卸売市場へ流通が集中し, 市場間の競争 が激化している.

本報告では，このような状況下で，資金力や市 場規模が小さくとも経営を維持している「その他 卸売市場」に着目し, 岡山県の卸売市場 3 社への ヒアリング調査を行った，その結果に基づき，そ の他卸売市場がその機能をいかに発揮しているか, 経営維持のために今後いかに対策を講ずるべきか を明らかにし，その他卸売市場の生き残り戦略に ついて考察する。 scale wholesale markets that persist with their management strategy under such situations, despite being small in size.

This paper analyzes the management strategy of three companies in the wholesale market of Okayama prefecture on the basis of a hearing investigation and proposes an effective management strategy for companies in small-scale wholesale markets.

\section{2. 卸売市場の概要}

\section{（1）卸売市場の現状}

農産物の市場経由率は年々低下傾向にある。主な 要因に，(1)運搬・情報技術の発展による流通チャネ ルの多様化，(2)市場を介さない輸入野菜の増大，な どがあげられる。

卸売市場は，中央卸売市場法制定当初，「すべて の人に安定した食料の供給を行ら」ことを目的に, その普及に力点を置いた政策が取られてきた。しか 乙全国的に整備が完了し，消費者の食生活が量的に 満たされると，食品への安全・安心志向や質に対す る意識が高禾った．現行の第 8 次卸売市場整備計画 では「集荷力の向上」と「品質管理の徹底」のため 飞, 卸売市場の統廃合, 規制緩和が進められている. 流通の効率化政策に加光，川上・川下の大型化が起 こった結果，大型卸売市場へ流通が集中するように なった。

このように，市場外流通との競合に加光，卸売市 場間でも競争が激化している。ささらに，不況による 
農産物価格の低迷と売孔行き不振で, 経営難に直面 している卸売市場は少なくない。

\section{（2）その他卸売市場の制度的位置づけ}

卸売市場は, 中央卸売市場, 地方卸売市場, その 他卸売市場の 3 種類に区別される. このらち「その 他卸売市場」は開設者, 市場面積, 要件に関して卸 売市場法による規定がなく, 中央卸売市場および地 方卸売市場以外の「規模未満市場」として扱われて いる，法規制がないため，価格形成や決済に関する 規定もなく，各市場の実情により異なる方法が取ら れていることが多い.

小規模な市場は，資金力の低さや市場面積の狭さ なぞが原因で，流通の効率化のための設備の充実を 大規模市場のよらに行えない。 また, 集荷力が大規 模市場と比較し劣るために，市場間競争での「生き 残り」が困難であると考它られる．2007（平成 19) 年時点で全国 599 社のその他卸売市場が経営活動を 続けているが, その情報は非常に少なく, 実態は不 明瞭である.そこで，次節で岡山県内の卸売市場の 動向についてまとめ, その他卸売市場が流通に沶い ていかに機能を発揮しているかを考察する.

\section{3. 岡山県内のその他卸売市場の動向}

\section{（1）株式会社浅原青果〜地産地消の推進〜}

\section{1）市場の概要}

1972（昭和 47）年，岡山県玉島市に，岡山市中 央卸売市場の荷受会社である株式会社浅原青果が同 名の市場を開設した。この地域には多くの仲卸業者 や問屋が集中して市場街を形成して招り, 長年地域 流通の拠点となってきた.

\section{2）集荷形態・売買参加者の特徵}

岡山市中央卸売市場打よび倉敷地方卸売市場から の相対による仕入れに加光, 地域の農家から相対取 引による委託販売を行っている. 主な売買参加者は 近隣のスーパーマーケットである.

\section{3）地域における役割}

当市場の役割を地産地消の推進による産地振興と 捉えて扣り，精力的に活動している。そのうちの一 つが，2004（平成 16）年に当社専務の浅原真弓氏 の呼びかけで主島市場内の玉島総合卸売組合 13 社 中 7 社で設立された「扔かやま玉島市場 LLP（有 限責任事業組合)」である. 当該 LLP は設立初年で 4500 万円, 2 年目には 6000 万円の売り上げを達成
している．以下にその三つの取り組みを紹介する。

\section{a. オリジナルブランド『みにくいやさいの子』}

玉島市場の集荷先である地域農家は，小規模ながら も地域に根ざした多種多様な野菜を出荷できるという 魅力がある．これを活かし，多少の傷や形の悪さなど で市場出荷に適さない野菜を買い取り,「見た目が劣っ ても新鮮で，旬の野菜」を『みにくいやさいの子』と して, 売買参加者のスーパーの一部にインショップ形 式で販売している.ブランドロゴに親しみやすいイラ ストを用いるなどの工夫により，倉敷市内のスーパー では一日平均 10 万円を売り上げている.

この取り組みによって生産者は収入の機会と地元 消費者といら顧客を創造する，消費者は地場農産物 を普段利用する店で買らことができる。すなわち， 『みにくいやさいの子』によって地産地消を実現し ていると言える。 また，当該 LLP では集荷先との コミュニケーションを積極的に行らために, 野菜の 情報やレシピなどを売り場に揭示している.さらに, 商品の陳列, 回収の際に把握できた消費者の反応を 生産者に伝えている. 生産者と消費者間の情報の架 け橋となることで, 地産地消のさらなる推進を図っ ている。

生産者は選果のみを行い, それ以降の包装，陳列， 回収などは当該LLPが行って扣り，労力がかかる ため取り扱い店舗の増加は困難である。しかし地産 地消の効果のほかに野菜の口スの軽減も望めるた め, この取り組みは他の地域に打いても良いモデル となるだろう。

\section{b. オリジナルブランド『芗桃』}

玉島地区は岡山県でも有数の白桃の産地である. ブランド立ち上げ以前はJA が「岡山の白桃ブラン ド」を独占している状態であり, 白桃農家では A 級品はJA へ, そ玌以外は市場へ出荷するのが一般 的であった．しかし，玉島地区の若手農家を中心に 「玉島の桃」であることを付加価値として個人的な 直接販売や，JA を介さず市場出荷を行らケースが 増加した。これを当該LLPは，『玉桃』として倉敷 市に申請し，2006（平成 18）年に認定された.

『玉桃』はさらに，ジュレ，アイスクリームなど 加工品の開発，全国に向けたインターネット販売な ぞで六次産業化した。 その結果玉島は「桃の産地 として全国的に知名度を上げ，農家の生産意欲向上 に繋がった. 


\section{c. もも祭り}

2004（平成 16）年より，毎年 7 月に白桃の PR イベ ント「も祭り」を開催している. これは，70 年以 上の歴史を持つ玉島市場で会社同士が協同した初め てのイベントである.これを機に市場のために連携 してできることはないかを考光るなど，当該 LLP 設立のきっかけともなった，現在では特別価格で販 売される白桃を求めて多くの消費者が集うイベント となっている. 白桃の他に特産物の販売, 市場の「せ り」のデモンストレーション，白桃のオリジナルレ シピを用いた食育活動など多岐にわたる催しで玉島 地区の農産物や市場のPR を行っている.

以上の取り組みに加光, 浅原氏は「玉島预か及さ 几会」を主宰している。この会は2004（平成 16) 年より産業振興による地域活性化を目標として設立 された。 以来, 主婦ならではの視点から地場農産物 を利用した商品のプロデュース活動や販路の確保を 行っている. 主な開発商品に前述の『みにくいやさ いの子』と高梁川流域のコラボレート商品「備中巻 寿司」,くらしき作陽大学との農産学連携による『玉 桃』の加工品などがある，材料をすべて岡山県産で 揃えるためコスト面が課題であるが，この六次産業 が新たな地域資源となることが期待されている.

\section{4）今後の展開}

和かやま玉島市場 LLP は 3 年を 1 クールとして おり，今年度から始まった 2 カール目も取り組反を 継続している. 3 年後の株式会社への移行なども検 討されている.

浅原氏の「地域を活性化したい」という熱意と精 力的な活動が周囲を動かし, その他卸売市場が「地 産地消の推進役」となった。 これはその他卸売市場 がLLPを結成することによって，流通の拠点とし ての機能を活かしながら，本来の役割を超えた事例 であると言える.

\section{（2）高梁食品総合卸売市場〜地域需要への対応〜 \\ 1）市場の概要}

高梁食品総合卸売市場は, 高梁市で食料品卸を行 ら高梁食品株式会社によって1972（昭和 47）年に 開設された. 青果物の年間取扱金額は約 1.8 億円で あり，減少傾向にあるという。主な取扱商品は，青 果物, 菓子, 食料加工品, 生活雑貨などである。な 抒, 当市場は「び注く農協青果市場」「高梁魚市場」 のとの他卸売市場 2 社が隣接している.

\section{2）集荷形態・売買参加者の特徵}

生鮮食品の集荷は, 岡山市中央卸売市場, 倉敷地 方卸売市場ですべて相対による仕入れを行ってい る. 主な売買参加者は地元の専門的小売商店，スー パーマーケット，サービス業，病院，加工工場，な どである.

\section{3）地域における役割}

この市場の特徵は，自らの役割を「顧客の仕入れ 代行」と位置づ, 地域の売買参加者, 消費者の二ズに対応した経営活動をしていることである.

当市場に隣接しているびほく農協青果市場は，管 内の組合員が作った青果物をせり取引とよって販売 している. 管内では促成栽培や抑制栽培が行われて おらず，売買参加者に安定した周年供給を提供でき ない，そこで当市場は，びほく農協の品揃え不足を 補らために岡山市中央卸売市場，倉敷地方卸売市場 からの仕入れを行っている．高梁魚市場は，1974（昭 和 49）年に移転してきた．3 社の集積は売買参加者に 幅広い品揃えを可能とし，市場の機能を高めている.

消費者に対しては，市場の経営維持自体が地域貢 献となっている．近年，大規模小売企業の台頭によ り専門的小売商店の売り上げ・店舗数は減少傾向に ある。高梁市も例外ではない，当市場はこれらを主 要な取引相手としているため, 収益にも影響が現れ た。しかし高梁市は2007 (平成 19）年の時点で高齢 化率が 34.0\%（岡山県内で 6 位） と高く，専門的小 売商店は高齢者の消費活動・住居地に近い，重要な 「買い物の場」となっている。また，病院など中山間 地域の施設の運営を支えるために，卸売市場は地域 の流通の拠点として経営を維持する必要がある。

\section{4）今後の展開}

市場を取り巻く環境の変化に合わせて市場も変化 しなければならず，当市場は経営維持のために取り 扱い品目の拡大を進めてきた．高梁食品株式会社の 設立当初は食料品卸を行っていたが，市場開設に よって青果物, 後に小売店の品揃え充実のために菓 子，日用雑貨，地域小売店の衰退に伴い業務用農産 物を取り扱うようになった。このように異業種への 参入を行わないことでリスクを抑えながら，売買参 加者の需要に応えている.

そして経営者は, 「地域に生活者が存在する限り, 流通の拠点として卸売市場は必要である。小規模な その他卸売市場だからこそ細やかなニーズに応じた 
集分荷が可能.」と，自らの役割を認識していた.

（3）美作青果卸売市場〜長年培った流通形態の維持〜

\section{1）市場の概要}

美作青果卸売市場は，1973（昭和 48）年岡山県 北東部農村地帯の流通の拠点として, 食料品卸売を 行ら株式会社矢野商店によって開設された。商品の 年間取扱高は約 7 千万円である. 美作市は鳥取県と 兵庫県に面して扮り, 国道沿いに位置するこの市場 は, 農産物直売所を有する道の駅とともに観光客に も利用されている. 卸売業務のほかに, 一般消費者 用の農産物や土産物の小売も行っている.

\section{2）集荷形態・売買参加者の特徵}

集荷は岡山市中央卸売市場での仲卸業務と, 長年 信頼関係を培った近隣の農家などから, ともに委託 販売と相対取引によって行っている. 取り扱い品目 は青果物, 調味料, 穀物など, 魚・精肉以外の食料 品は揃っている. 魚, 精肉については販売の権利は 持っているものの, 地域に取り扱ら農家が無いため 販売を行っていない.

売買参加者は地域の専門的小売商, 旅館などの サービス業, 病院, 学校給食, ファーマーズ・マーケッ トの売店などである. サービス業向けの野菜は市場 で皮むきなどの下ごしらえをしている. 小売業務で は家庭向け食料品と土産物の販売を行っている.

\section{3）地域における役割}

当市場の役割として，二点があげられている.

第一には，美作地区に打ける流通機能の維持であ る. 市場は消費者にとって身近な存在であり, 地域 の食生活を支えてきた. 現在は技術の発展により流
通チャネルが多様化したが，すべての消費者がそれ を利用するわけではない，市場を必要とする売買参 加者が存在する限り, 市場の経営維持は不可欠であ るといら考えのもと, 日常業務につとめている.

第二には，高品質な農産物の供給である。直売所 のように選果を農家のみに任せず，信頼関係を築い た農家から目の利く市場の担当者が仕入れるため, 品質の保証が可能である. 同時に, 農家とコミュニ ケーションをとることで情報交換を行い，生産意欲 を高めている。これは昔から美作地区の流通を支え てきた当市場だからこそできることであり，大きな 強みとしている.

\section{4）今後の展開}

前述の通り, 市場の経営維持が最重要である.今 後市場の経営を維持する上での課題として，11取引 量の減少，(2)傷んだ野菜など，ロスの廃棄にかかる 費用，があげられている（11については，美作市の 人口は減少傾向にあり, 店舗が飽和状態であるため 販路を増やすことは困難な状況にある。(2)は，集荷 後に起こるロスであるため, いわゆる「傷物」とし て売られている野菜に比べ鮮度で劣り, 再利用が困 難であるため廃棄するよりない. これらの対策とし て, くず野菜の加工品利用に加え, 「地域に市場は 不可欠である」といら消費者・行政の理解のもと, 補助金などの協力を求めたいとのことであった.

\section{4. 結果と考察}

調査を行った 3 社の事例分析結果を表 1 によとめ た．共通している点は，(1)長年かけて培った農家や

表 1. 岡山県内のその他卸売市場 3 社の事例分析

\begin{tabular}{|c|c|c|c|}
\hline 市場名 & 浅原青果 & 高梁食品総合卸売市場 & 美作青果市場 \\
\hline 設立年月日 & 1972（昭和 $47 ）$ 年 12 月 27 日 & $1972 （$ 昭和 $47 ）$ 年 12 月 25 日 & 1973（昭和 $48 ）$ 年 2 月 17 日 \\
\hline 所在地 & 倉敷市玉島 & 高梁市旭町 & 美作市林野 \\
\hline 主な集荷先 & $\begin{array}{l}\text { 岡山市中央卸売市場, } \\
\text { 倉敷地方卸売市場, 地域農家 }\end{array}$ & $\begin{array}{l}\text { 岡山市中央卸売市場 } \\
\text { 倉敷地方卸売市場 }\end{array}$ & $\begin{array}{l}\text { 岡山市中央卸売市場 } \\
\text { 地域農家・地主 }\end{array}$ \\
\hline 売買参加者 & スーパーマーケット & $\begin{array}{l}\text { 専門的小売商, スーパーマーケッ } \\
\text { ト, サービス業，病院 }\end{array}$ & $\begin{array}{l}\text { 専門的小売商, ファーマーズマー } \\
\text { ケット, 学校給食, サービス業 }\end{array}$ \\
\hline 主な取扱品目 & 青果物 & 青果物, 加工品, 菓子, 生活雑貨 & 青果物, 加工品, 調味料 \\
\hline 地域での役割 & $\begin{array}{l}\text { 地産地消の推進による地域振興 } \\
\rightarrow \text { おやかま王島市場 LLP・玉島お } \\
\text { かみさん会主宰 }\end{array}$ & $\begin{array}{l}\text { 顧客の仕入れ代行, } \\
\text { 取扱品目の充実 }\end{array}$ & $\begin{array}{l}\text { 市場機能の維持, 生産者との信頼 } \\
\text { 関係に基づく高品質農産物の提供 }\end{array}$ \\
\hline
\end{tabular}

資料：ヒアリング調査に基づき筆者作成 
売買参加者との信頼関係を重要視している, (2)地域 に打ける自らの役割を見出して扣り，経営維持に前 向きであること，であった，とくに(1)は容易には得 られない強みである。食の安全・安心志向が高まっ ている昨今, 冷蔵庫などの設備投資による品質保持 機能の強化が注目されている. しかし, 安全性や品 質の保証で最も重要なものの一つは「人」と「人」 との信頼関係であろら.

また，規制の緩さ，規模の小ささによる細やかな 集分荷が可能である点は，大規模市場には無いその 他卸売市場に共通の強みである. 高梁食品総合卸売 市場や美作青果卸売市場のような中山間部の卸売市 場では，この強みを活かしながら「地域流通の拠点」 であり続けることが生き残り戦略の基礎と言えよう.

一方, 県南の都市部周辺に位置する浅原青果は, 集荷ルートや販路を活かした卸売市場の機能を超え た取り組みにより，地域振興の推進役としてもなく
てはならない存在になっていた。

卸売市場法改正による規制緩和や市場外流通の発 達により，今後農産物流通はより多様かつ重層的な ものになることが考えられる。その他卸売市場が自 らの強みを意識し，それを生産者・売買参加者をは じめとする利用者に伝えることが事業体としての生 き残りを可能にし，同時に地域の農産物流通を円滑 化するだろう。

\section{参考文献}

［1］細川允史「卸売市場」『食糧・農産物の流通と市 場 II』日本農業市場学会編，筑波書房，2008 年.

［2］岡山県「岡山県毎月流動人口調査」

[3] 農林水産省「第 8 次卸売市場整備基本方針」 2007 年.

［4］農林水産省「平成 20 年度卸売市場データ集」

［5］東海農政局「卸売市場対策」 